\title{
Use of palmae wax hydrocarbon fractions as chemotaxonomical markers in Butia and Syagrus
}

\author{
Paroul, N. ${ }^{\text {*, }}$ Cansian, RL. ${ }^{\mathrm{a}}$, Rossato, M. ${ }^{\mathrm{b}}$, Pauletti, GF. , \\ Serafini, LA. ${ }^{\mathrm{b}}$, Rota, L. $^{\mathrm{b}}$, Moyna, ${ }^{\mathrm{c}}{ }^{\mathrm{c}}$ and Heinzen, $H^{\mathrm{c}}{ }^{\mathrm{c}}$ \\ aDepartamento de Química, Universidade Regional Integrada do Alto Uruguai e das Missões - URI, \\ Av. Sete de Setembro, 1621, CEP 99700-000, Erechim, RS, Brazil \\ 'Instituto de Biotecnologia, Universidade de Caxias do Sul - UCS, \\ Rua Getulio Vargas, 1130, CEP 95070-560, Caxias do Sul, RS, Brazil \\ 'Facultad de Química, Universidad de la República - UDELAR, \\ Av. General Flores, 2124, CP 11800, Montevideo, Uruguay \\ *e-mail: nparoul@uricer.edu.br \\ Received June 1, 2007 - Accepted August 20, 2007 - Distributed May 31, 2009
}

(With 5 figures)

\begin{abstract}
The wax hydrocarbon fractions of native Butia and Syagrus species collected from Palms in different regions of the of Rio Grande do Sul state (Brazil) and in Rocha (Uruguay) were analyzed to evaluate their potential as chemotaxonomic markers. The wax was extracted with chloroform and the resulting wax was fractionated by preparative TLC. The hydrocarbon fractions were analyzed by GC-MS. Statistical analyses were completed with the Statistica 5.0 program. The total crude wax yields averaged $0.31 \%$ w. $\mathrm{w}^{-1}$ dried leaves for Butia samples and $0.28 \%$ for Syagrus samples. The linear hydrocarbons represented on average $15 \%$ of the total waxes in the case of Butia samples and $13.7 \%$ in Syagrus samples. Hentriacontane and triacontane were the main components of all samples. The comparison of the means showed significant differences among Butia and Syagrus samples, and amongst Butia samples collected in different localities. In the case of the Syagrus collections no consistent groupings could be made. In the case of Butia samples the formation of three groupings could be observed, which were consistent with the species described for their geographical distribution. These results are discussed in the paper.
\end{abstract}

Keywords: epicuticular waxes, chemotaxonomic markers, hydrocarbons, Butia, Syagrus.

\section{Uso de frações de hidrocarbonetos de palmeiras como marcadores quimiotaxonômicos em Butia e Syagrus}

\begin{abstract}
Resumo
Frações de hidrocarbonetos das ceras de espécies nativas de Butia e Syagrus coletadas de palmeiras em diferentes regiões do Rio Grande do Sul (Brasil) e em Rocha (Uruguai) foram analisadas para avaliar o seu potencial como marcadores quiomiotaxonômicos. As ceras foram extraídas com clorofórmio e fracionadas por TLC preparativo. As frações de hidrocarbonetos foram analisadas por CG-EM. As análises estatísticas foram realizadas com auxílio do programa Statistica 5.0. O rendimento total de cera das folhas secas foi de $0,31 \% \mathrm{~g} . \mathrm{g}^{-1}$ para as amostras de Butia e de $0,28 \%$ para Syagrus. Os hidrocarbonetos lineares representaram em média 15 e $13 \%$ do total das ceras para Butia e Syagrus, respectivamente. Hentriacontano e triacontano foram os compostos majoritários em todas as amostras. A comparação de médias mostrou diferenças significativas entre as amostras de Butia e Syagrus e entre as amostras de Butia coletadas em diferentes localidades. As amostras de Syagrus não formaram agrupamentos relacionados com os locais de coleta. Já no caso de Butia, três agrupamentos puderam ser observados e são consistentes com a distribuição geográfica desta espécie. Estes resultados são discutidos no trabalho.
\end{abstract}

Palavras-chave: ceras epicuticulares, marcadores quimiotaxonômicos, hidrocarbonetos, Butia, Syagrus. 


\section{Introduction}

Palmae is an extremely interesting botanical group, which represents one of the main evolutionary lines for Monocots. Their distribution is pan-tropical, with only a few species adapted to cooler climates (Tomlinson, 1961; Corner, 1966; Lotschert, 1985). The study of the group is difficult, as their collection involves extensive explorations and expeditions, while the preparation of herbarium samples is very complex. Studies have been generally carried out in specialized collections in arboreta, usually in botanical gardens located in tropical regions or established in glass-houses, which can be the largest buildings in these institutions. Although the Palmae have always attracted the interest of the most important botanists, these factors have reduced their scientific study.

The group has immense commercial and industrial importance, and many species are the origin of edible and industrial oils, waxes and fibres of multiple uses (Del Cañizo, 1991). Certain species have their growth centres used as food, some have edible fruits or yield syrups used for fermented drinks (Jones, 1994). Thus, where Palms grow naturally or where they can adapt easily, palms are exploited commercially and can represent important economic benefits for the native inhabitants (Balick, 1988).

The taxonomic classification for this huge Family (2,500 to 3,500 described species) is traditionally based on the morphological characteristics of trunks, leaves, fruits and flowers, in the anatomical peculiarities of their organs, in the cytology of tissues, including the description of the pollen grains, studies on the present day geographical distribution, and of the evolutionary study of the Family and its genera (Glassman, 1972; Moore and Uhl, 1982; Henderson, 1988).

Approximately one fourth of all known Palmae are native to the Americas, and more than 60 of the genera described are present, and several are exclusive, to the New World. In the southern countries of South America there are over 70 native genera. Of these, 37 have been described for Brazil, 21 in Bolivia, 10 in Paraguay, 7 in Argentina, 3 in Uruguay and 1 in Chile (Glassman, 1972; Reitz, 1974; Henderson et al., 1995; Cerqueira and von Behr, 2004). The more common species in the Southeastern region are related to Butia and Syagrus genera, and represent interesting taxonomical problems, as their specific morphological (differences) traits are vague (Reitz, 1974; Cerqueira and von Behr, 2004), and having been exploited by humans from pre-Columbian times with the resulting artifactual overlapping of species, sub-species and hybrids (Lombardo, 1964; Iriarte et al., 2005).

Some secondary metabolites, such as flavonoids and anthocyanins (from the shikimate pathway) and certain epicuticular wax constituents have been shown to be excellent taxonomical markers in other botanical groups (Lombardo, 1964; Vieira et al., 2001). The epicuticular waxes that cover the surfaces of leaves, green twigs, fruits and flowers of plants behave as barriers between the individual plants and their environment, are principal factors in avoiding their dehydration and water permeation, resulting in a stable internal milieu (Kolattukudy, 1976)

As the epicuticular waxes (Figure 1) are external to plants, and thus not involved in their metabolic cycles, their compositions are quite stable, reacting only with a few environmental agents. More than one chemical marker can be enclosed in a wax, and their presence or absence reflects the specificities of the enzymes involved in the series of biosynthetic steps leading to the production of hydrocarbons, fatty acids, fatty alcohols or their esters, or on constituents that have their origin in squalene oxide, leading to steroids and/or pentacyclic triterpenes (Xu et al., 2004). Some have a valuable taxonomical nature, as is the case of pentacyclic triterpene methyl ethers, which are specific to Monocots, and are particularly important in Palmae (García et al., 1995; Escalante-Erosa et al., 2002).

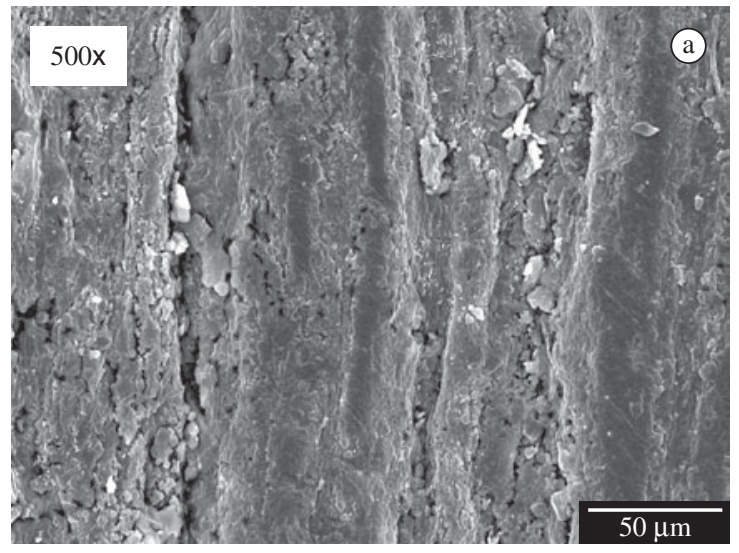

(HUCS 11255)

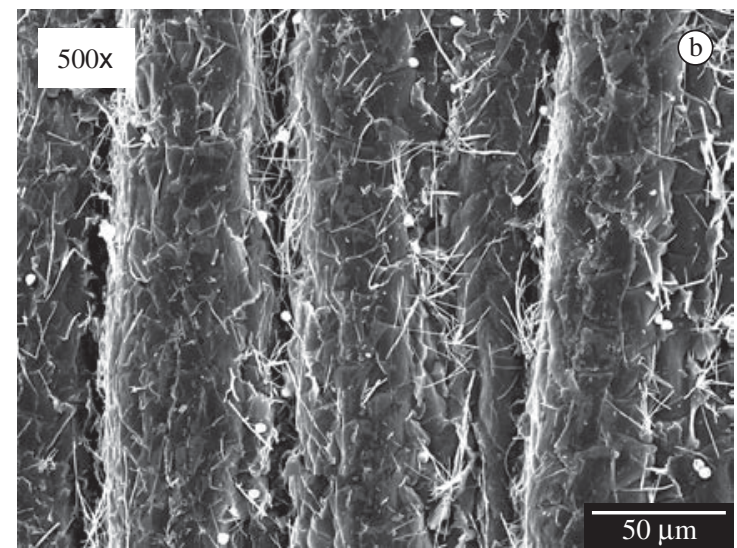

(HUCS 13994)

Figure 1. SEM microphotographs for leaf dorsal surfaces of Butia a) and Syagrus b), at 500x enhancement. 
The stability or instability of the chemical parameters (quali- and quantitative variations) is what can establish the real value of a component as a useful taxonomical marker at the species level, and the statistical analyses of the chemical data can give us indications to their adequacy (Maffei and Scannerini, 1993). One aspect that has not received much attention in this context is the variation of intra-specific phenotypic expression, which depends on environmental factors, as well as the age and general situation of each individual (Vieira et al., 2001).

In the present study, the hydrocarbon fractions of two native groups, Butia and Syagrus were analyzed. The samples were collected in the regions of the Serra Gaucha, Atlantic Littoral and the Planalto (Missões) of Rio Grande do Sul (Brazil), and Rocha (Uruguay), with the aim of establishing their value as taxonomic markers and to correlate their compositions with proposed species and geographical origins.

\section{Material and Methods}

\subsection{Sample collection and preparation}

24 Butia leaf samples and 20 Syagrus leaf samples were collected in the Serra Gaucha, Atlantic Littoral and Planalto (Missões) of the State of Rio Grande do Sul (Brazil/ and Rocha (Uruguay) (Figures 2 and 3). Voucher samples were deposited at the Herbário (HUCS) and Banco Ativo de Germoplasma (BAG) of the Universidade de Caxias do Sul

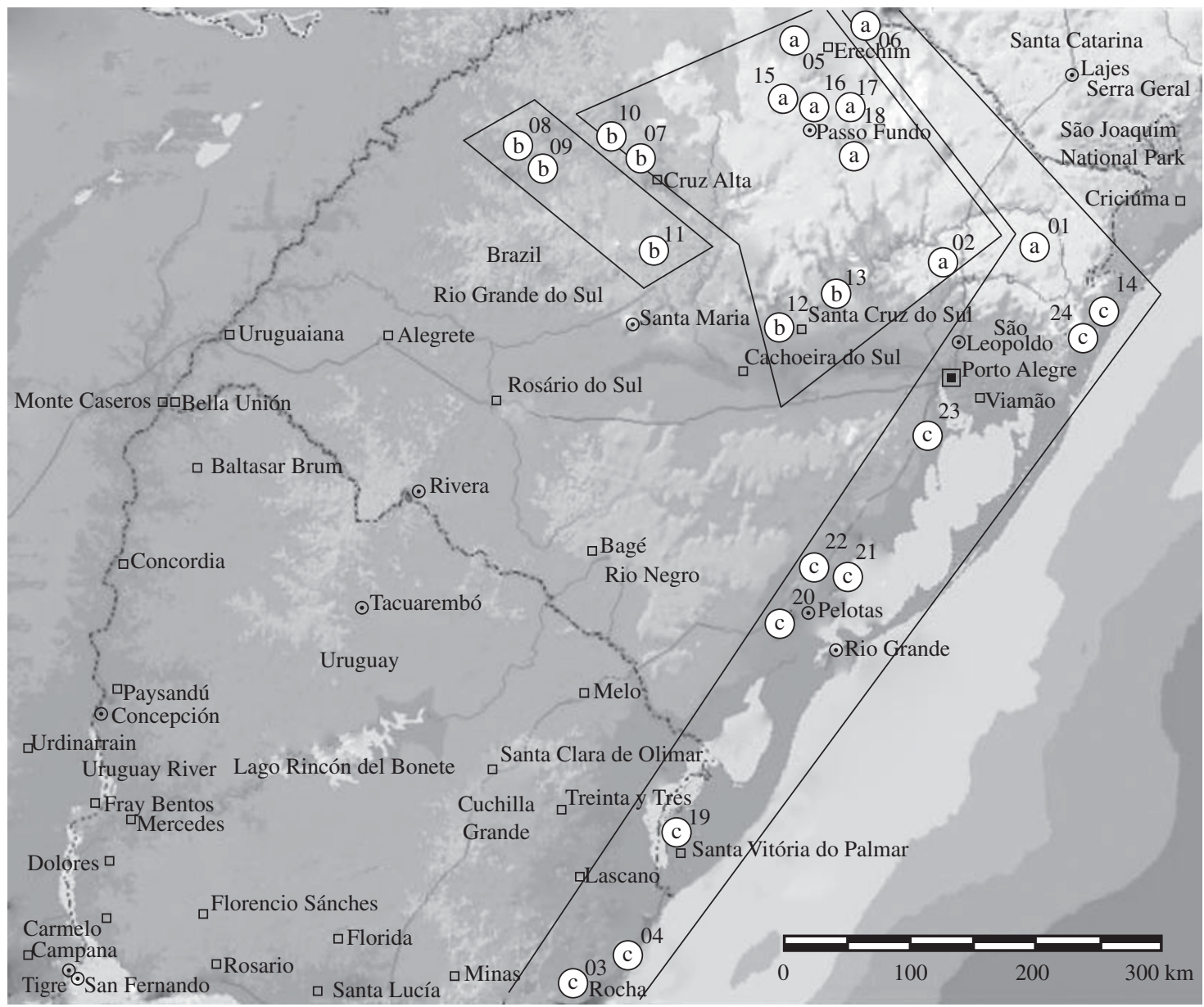

Figure 2. Geographical distribution of the Butia collections. 1) Jaquirana (HUCS 13605); 2) Caxias do Sul (HUCS 24693); 3) Uruguay (HUCS 15170); 4) Uruguay (BAG 005); 5) Erechim (HUCS 13996); 6) Erechim (HUCS 22585); 7) Ijuí (HUCS 14271); 8) São Miguel das Missões (HUCS 14272); 9) Entre Ijuis (HUCS 24698); 10) Entre Ijuis (HUCS 14271); 11) Tupanciretã (HUCS 24800); 12) Santa Cruz do Sul (BAG 010); 13) Bom Retiro do Sul (BAG 010); 14) Morro Azul (HUCS 14274); 15) Sertão (BAG 004); 16) Coxilha (BAG 005); 17) Coxilha (HUCS 27380); 18) Passo Fundo (HUCS 27379); 19) Santa Vitória do Palmar (HUCS 24802); 20) Pelotas (HUCS 24604); 21) São Lourenço do Sul (HUCS 24804); 22) São Lourenço do Sul (HUCS 27926); 23) Barra do Ribeiro (HUCS 22586); 24) Morro Azul (HUCS 14274). a) Planalto and Serra Gaucha (Altitude over 600 m); b) Missões and Depressão Central (Altitude from 300 to 500 m); and c) Littoral (Altitude below $200 \mathrm{~m}$ ). 


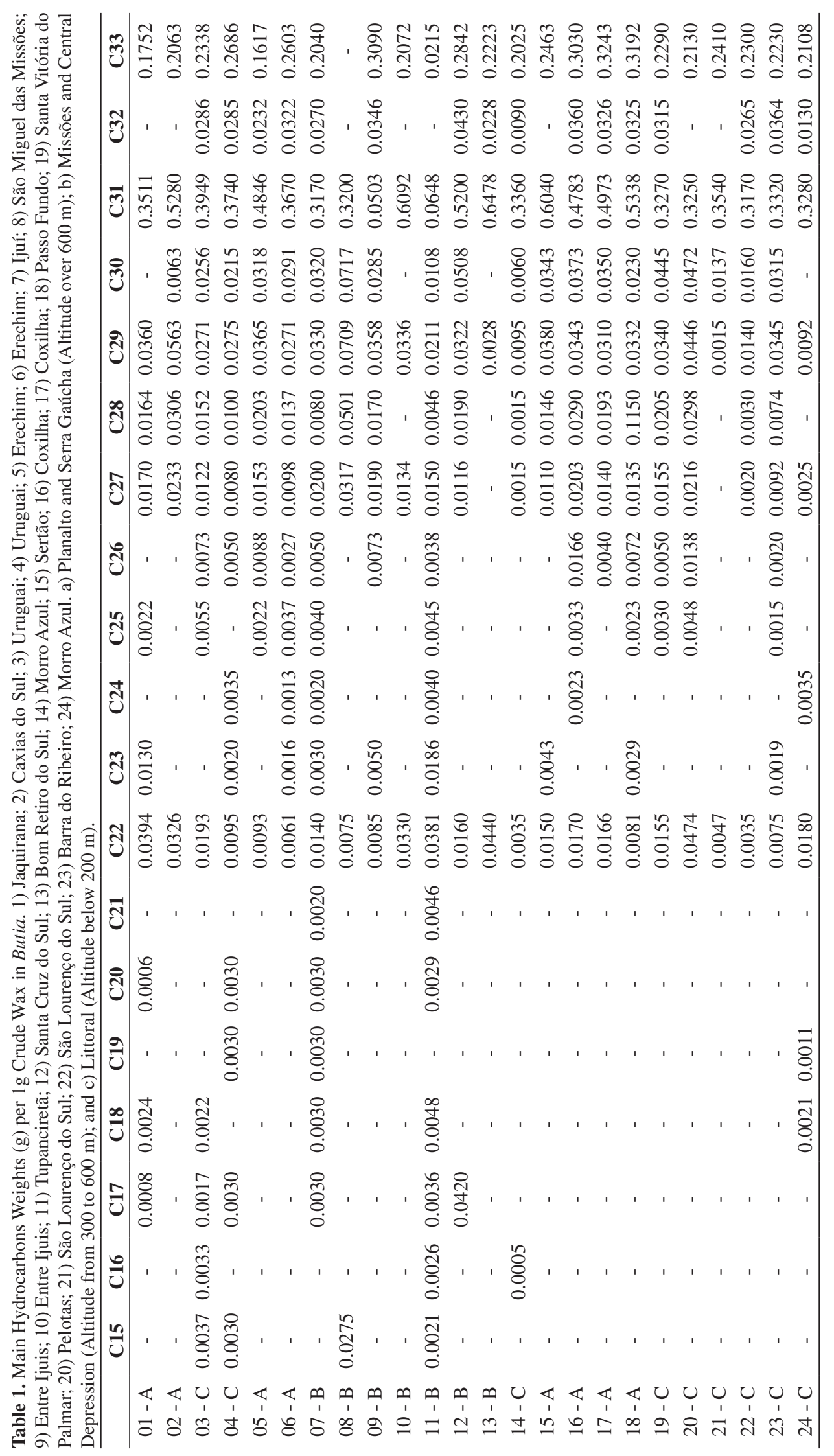




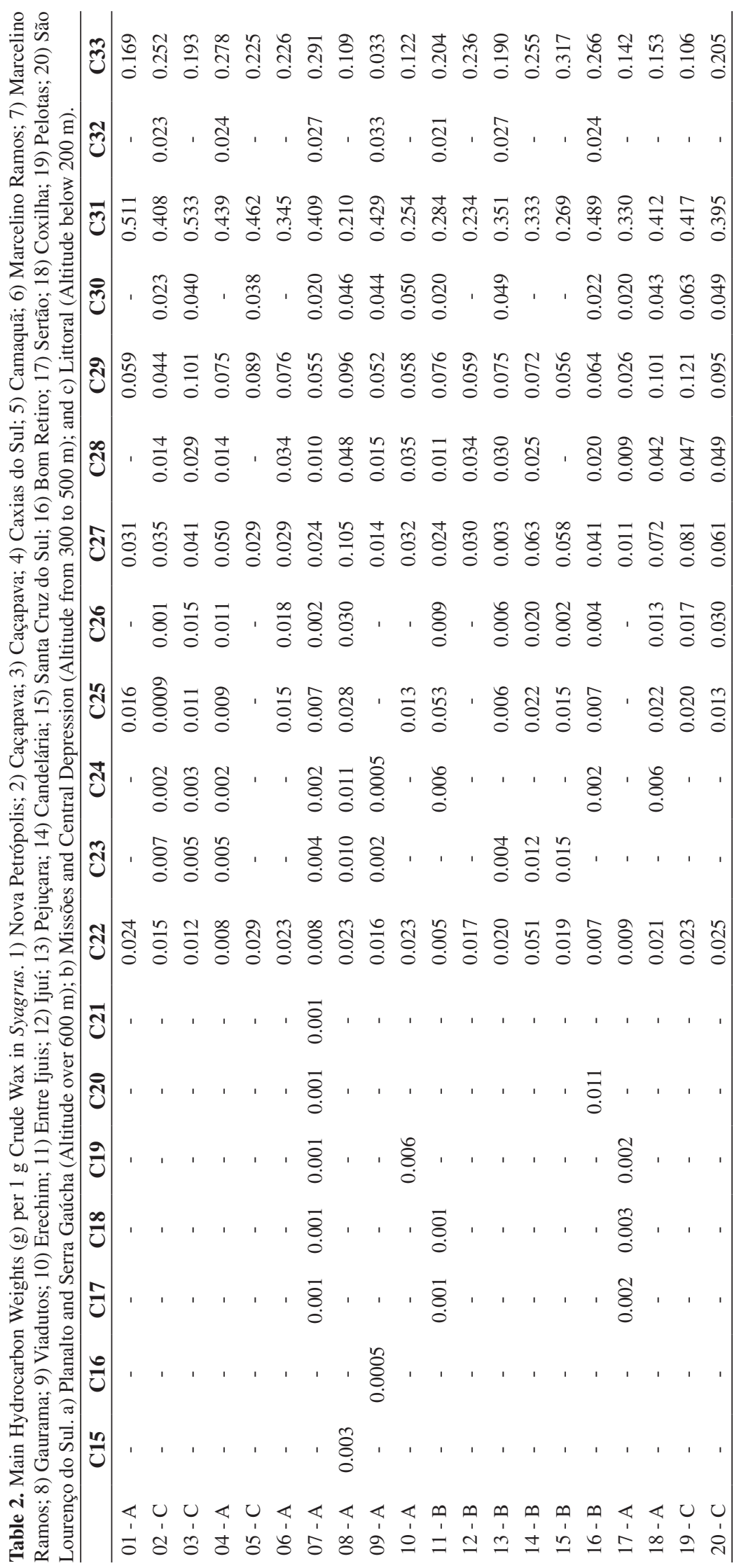




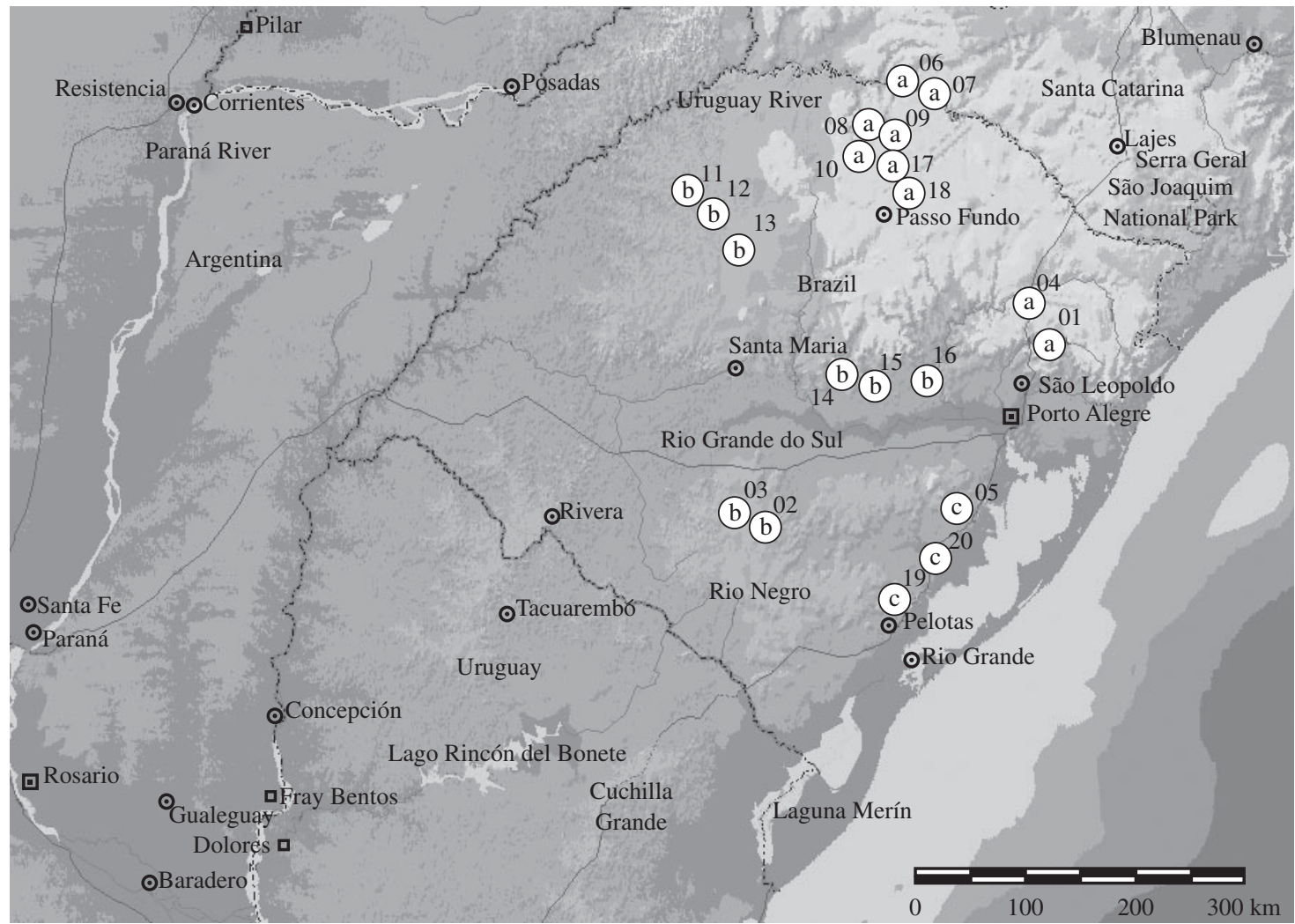

Figure 3. Geographical distribution of Syagrus collections. 1) Nova Petrópolis (HUCS 13330); 2) Caçapava (BAG 001); 3) Caçapava (BAG 002); 4) Caxias do Sul (BAG 003); 5) Camaquã (BAG 013); 6) Marcelino Ramos (BAG 006); 7) Marcelino Ramos (HUCS 13994); 08) Gaurama (BAG 006); 09) Viadutos (BAG 006); 10) Erechim (BAG 006); 11) Entre Ijuis (BAG 007); 12) Ijuí (BAG 008); 13) Pejuçara (BAG 008); 14) Candelária (HUCS 14273); 15) Santa Cruz do Sul (BAG 009); 16) Bom Retiro (BAG 011); 17) Sertão (HUCS 13994); 18) Coxilha (HUCS 13994); 19) Pelotas (BAG 015); 20) São Lourenço do Sul (BAG 016). a) Planalto and Serra Gaucha (Altitude over 600 m); b) Missões and Depressão Central (Altitude from 300 to 500 m); c) Littoral (Altitude below $200 \mathrm{~m}$ ).

(Figures 2 and 3). The leaves were separated from the stems and dried at $35^{\circ} \mathrm{C}$ until constant weight.

\subsection{Wax extraction and fractionation}

$100 \mathrm{~g}$ of dry leaves were washed using chloroform (40 seconds). The solvent was removed under vacuum in a rotary evaporator.

The residues were fractionated by Preparative Thin Layer Chromatography using Silica Gel plates, with hexane as development solvent. The hydrocarbon fractions were separated on the basis of the Rf of an authentic sample of icosane (Sigma-Aldrich Co.). For spot development a mixture of $\mathrm{CuSO}_{4} 5 \%$ (aq.) and $\mathrm{H}_{3} \mathrm{PO}_{4} 10 \%$ (aq.) (1:1) was sprayed, with heating in an oven to complete the process.

\subsection{Chromatographic analysis}

The isolated hydrocarbon fractions were analyzed using a Gas Chromatograph coupled to a Mass Spectrometer (Shimadzu CG 17A, CG/EM, QP 5050A), in sweep mode, using a DB-5 capillary column
(30 $\mathrm{m} \times 0.25 \mathrm{~mm} \times 0.25 \mu \mathrm{m})$. The column temperature was programmed at $100{ }^{\circ} \mathrm{C}$ (2 minutes); 250 to $300{ }^{\circ} \mathrm{C}$ at a rate of $2{ }^{\circ} \mathrm{C} / \mathrm{min}$.; 10 minutes at $300{ }^{\circ} \mathrm{C}$. Helium gas was used as carrier. Injector temperature was $290^{\circ} \mathrm{C}$ and detector temperature was $310^{\circ} \mathrm{C}$. The injection was done in the split mode (ratio 1:50), with electronic impact at $70 \mathrm{eV}$. Biphenyl (Sigma-Aldrich) at $100 \mathrm{mg} . \mathrm{L}^{-1}$ concentration was used as internal standard. Peaks were integrated manually, and quantitation was achieved by comparison with the internal standard. Constituents of the sample were identified comparing their retention times to those of authentic compounds (n-pentacosane, n-heptacosane, n-nonacosane, n-hentriacontane and ntritriacontane - Sigma-Aldrich) and their mass spectra with those of the Wiley Library.

\subsection{Scanning electronic microscopy}

The dried leaves were metalized by gold sputtering and their SEM microphotographs recorded with a Jeol Scanning Electron Microscope JSM-5900LV, at the SEM 
facilities of the Núcleo de Servicios de Alta Tecnología, Facultad de Ciencias, UDELAR, Montevideo, Uruguay.

\subsection{Statistical analysis}

Samples were injected three times and the statistical analyses for means comparisons (Tukey and $t$-Student, $\mathrm{p}<0.05$ ) and of groupings (Euclidian distance with simple links) were made with the Statistica 5.0 program.

\section{Results and Discussion}

The average yields of crude epicuticular waxes on dry leaves were $0.31 \%$ for Butia leaves and $0.28 \%$ for Syagrus leaves. Saturated linear hydrocarbons are, on average, $15.3 \%$ of Butia wax extract and $13.7 \%$ of Syagrus waxes. SEM microphotographs were recorded to observe the distribution of the waxes on the surface. Figure 1 shows typical distributions.

The GC-MS analysis permitted the identification and quantification of 19 hydrocarbons $\left(\mathrm{C}_{13}\right.$ to $\left.\mathrm{C}_{33}\right)$ in the Butia and Syagrus samples. The hydrocarbons of higher molecular weights are present in all samples (Tables 1 and 2), while the lower weight hydrocarbons were present as traces in most samples (less than $0.001 \mathrm{~g} \mathrm{~g}^{-1}$ of the fraction). Hentriacontane $\left(\mathrm{C}_{31}\right)$ and tritriacontane $\left(\mathrm{C}_{33}\right)$ are responsible for $81.7 \%$ of the total mass of the Butia hydrocarbons and $72.3 \%$ in Syagrus samples. Higher concentrations of high molecular weight hydro- carbons, which should result in higher melting ranges and less water permeability, seem to be an important evolutionary strategy for the Family, as they would also imply higher resistance to insect attack and climatic variations.

Significant differences (Tukey $\mathrm{p}<0.05$ ) in the average masses of the main hydrocarbons happened both in Butia as in Syagrus. The means comparison analysis following the $t$-Student Test for independent samples $(\mathrm{p}<0.05)$, showed significant differences in the concentration of the main hydrocarbons both in Butia and Syagrus, with the exception of docosane $\left(\mathrm{C}_{22}\right)$.

The grouping of populations made through Euclidian distances through simple links of the quantitative differences of the hydrocarbons analyzed, allowed the separation of all the samples.

For Butia samples the statistical analysis showed the formation of two main groups, with 3 samples outside of these populations. The relation of these groups with their geographical distribution and traditional species descriptions is shown in Figures 2 and 4. Group 1, with high similarity of compositions, included all samples collected in the Littoral of Rio Grande do Sul and in the Uruguayan coast, as well as samples from Jaquirana, Erechim e Ijuí. Some authors (Cerqueira and von Behr, 2004) describe this as the habitat Butia capitata var. odorata (Barb. Rodr.) Becc. The outlying samples from

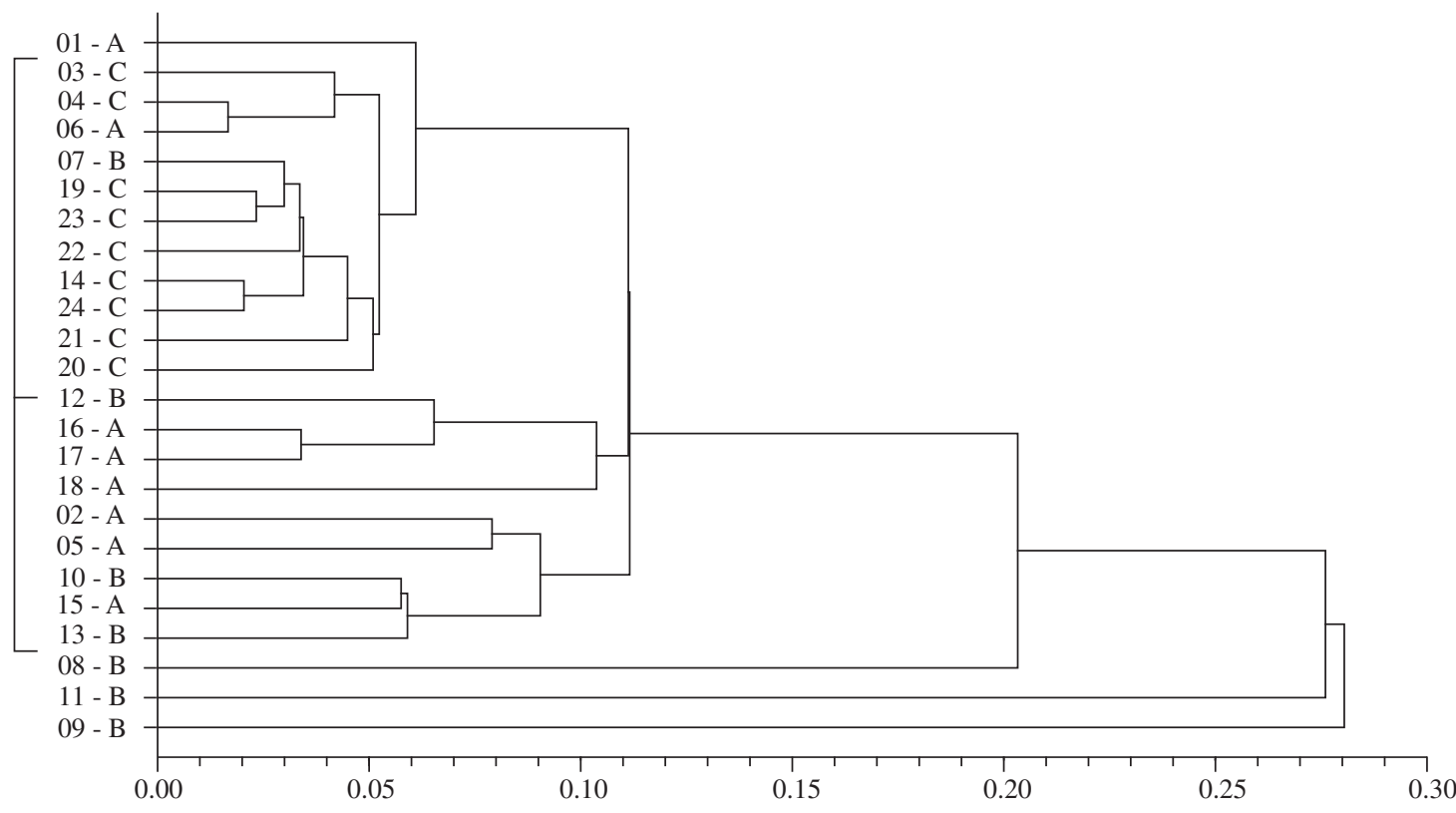

Figure 4. Analysis of Butia samples from the different geographical origins using Euclidian distances with simple links of the concentration of the hydrocarbons. 1) Jaquirana; 2) Caxias do Sul; 3) Uruguay; 4) Uruguay; 5) Erechim; 6) Erechim; 7) Ijuí; 8) São Miguel das Missões; 9) Entre Ijuis; 10) Entre Ijuis; 11) Tupanciretã; 12) Santa Cruz do Sul; 13) Bom Retiro do Sul; 14) Morro Azul; 15) Sertão; 16) Coxilha; 17) Coxilha; 18) Passo Fundo; 19) Santa Vitória do Palmar; 20) Pelotas; 21) São Lourenço do Sul; 22) São Lourenço do Sul; 23) Barra do Ribeiro; 24) Morro Azul. a) Planalto and Serra Gaúcha (Altitude over 600 m); b) Missões and Depressão Central (Altitude from 300 to 500 m); c) Littoral (Altitude below 200 m). 
the Serra Gaucha, Planalto and Missões are probably results of anthropic activities.

Group 2, with greater variability, was also geographically coherent, with most samples coming from the regions of Serra Gaucha and Planalto, which corresponds to the habitat of B. eriospatha Becc (Cerqueira and von Behr, 2004). The samples collected in São Miguel das Missões, Entre Ijuis and Tupanciretã, all in the Missões region, to the Northwest of Rio Grande do Sul, could not be related to Groups 1 or 2, did not establish a coherent group themselves, and can be related to other Butia species, particularly B. paraguayensis (Barb. Rodr.) L. H. Bailey and B. yatay (Mart.) Becc (Cerqueira and von Behr, 2004). Thus, the different groupings made by average masses of the main hydrocarbons in the waxes could reflect interspecific differences, something that would make them very useful taxonomic markers.

In the case of $S$. romanzoffiana (Cham.) Glassman, statistical analysis shows the formation of only one group, with the exception of the sample from Viadutos (Figure 5). Groups can be established, but they are statistically much less consistent than those for Butia (Figure 5), and which show no relevant connection with their geographical origin (Figure 3). Although sub-species with a less defined sub-regional distribution could be the case for Syagrus, other evaluations also seem to point to the presence of one species in all its distribu- tion range (Iriarte et al., 2005). In the case of these populations, factors connected with the microclimate, age of the plant or leaves, sunlight, soil, nutritional level, etc., which were not considered in the present study but have been discussed by Vieira et al. (2001) should be considered. Although some authors (Cerqueira and von Behr, 2004) mention 32 Syagrus species in Brazil, S. romanzoffiana (Cham.) Glassman seems to be the only abundant species in the Southern region.

\section{Conclusions}

The epicuticular waxes of Butia and Syagrus have high contents of linear hydrocarbons, with hentriacontane $\left(\mathrm{C}_{31}\right)$ and tritriacontane $\left(\mathrm{C}_{33}\right)$ being the main constituents. Differences in the individual hydrocarbon contents were observed in the compositions of both Genera. The statistical analysis of the hydrocarbon fractions in Butia established two distinct groups and a few outliers, which could be connected to their geographical origin and to the species traditionally described for each region. In the case of Syagrus waxes no groupings could be established. The small differences could be associated to environmental responses or to the existence of subspecies. The study of the wax linear hydrocarbon compositions seems to be a useful tool in the taxonomical study of the Palmae.

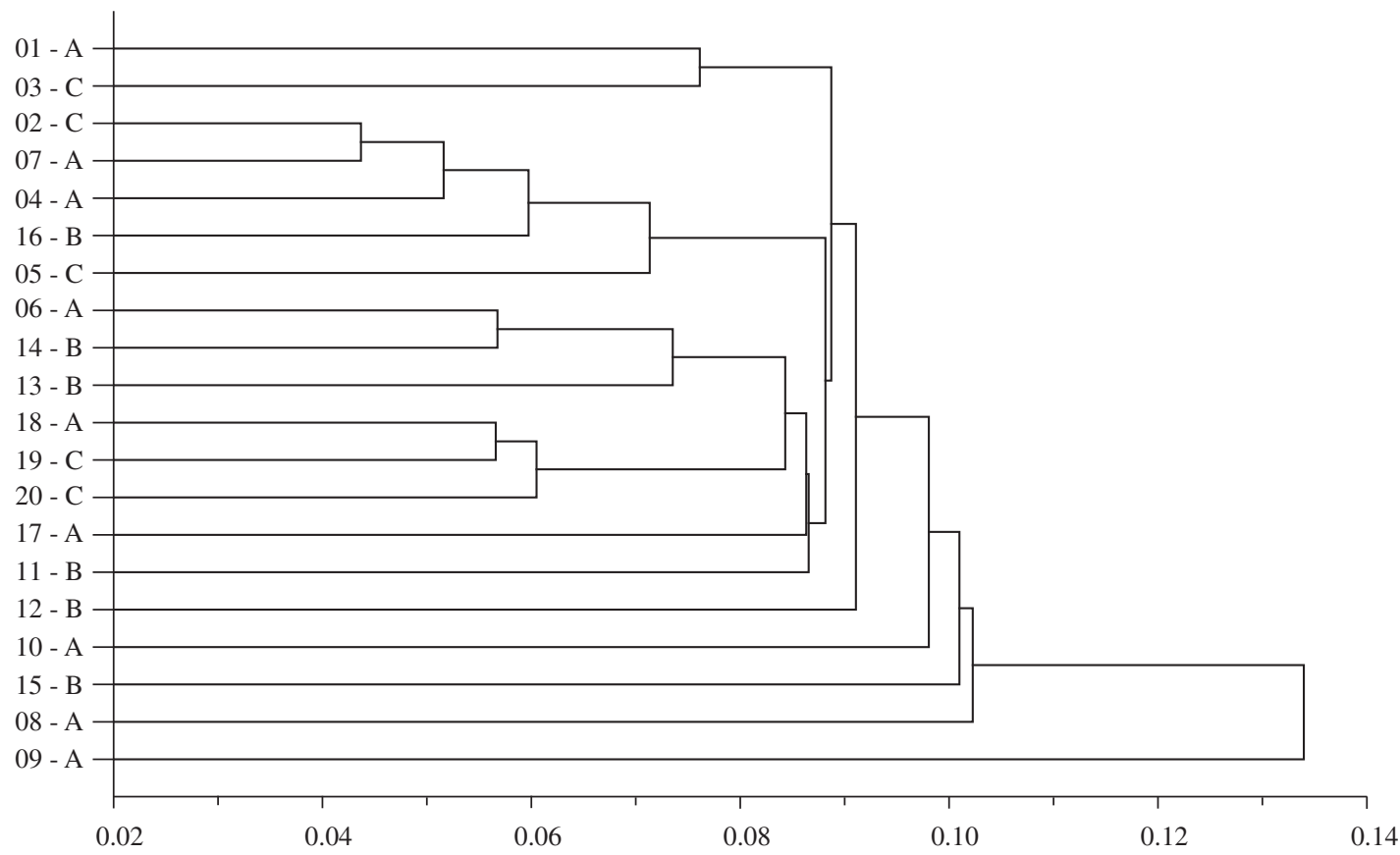

Figure 5. Analysis of Syagrus samples from the different geographical origins using Euclidian distances with simple links of the concentration of the hydrocarbons. 01) Nova Petrópolis; 02) Caçapava; 03) Caçapava; 04) Caxias do Sul; 05) Camaquã; 06) Marcelino Ramos; 07) Marcelino Ramos; 08) Gaurama; 09) Viadutos; 10) Erechim; 11) Entre Ijuis; 12) Ijuí; 13) Pejuçara; 14) Candelária; 15) Santa Cruz do Sul; 16) Bom Retiro; 17) Sertão; 18) Coxilha; 19) Pelotas; 20) São Lourenço do Sul. a) Planalto and Serra Gaúcha (Altitude over 600 m); b) Missões and Depressão Central (Altitude from 300 to 500 m); c) Littoral (Altitude below $200 \mathrm{~m}$ ). 
Acknowledgements - The authors are indebted to Drs. L. Noblick and M.Rivas for useful comments and insights. The authors (NP, RLC, MR and GFP) are grateful for the support received from URI-Campus de Erechim and UCS (Brazil) that made their work possible, and to the Science and Technology Secretariat and FAPERGS (RS, Brazil) for financing purchases of equipment. PM and HH thank the financial support of CSIC (UDELAR, Uruguay), and PDT (DINACYT- Uruguay).

\section{References}

BALICK, MJ., 1988. The palm-tree of life: biology, utilization and conservation. Advances in Economic Botany, vol. 6.

CERQUEIRA, LSC. and Von BEHR, N., 2004. Palmeiras no Brasil. São Paulo: Plantarum.

CORNER, EJH., 1966. The natural history of palms. London: Weidenfeld and Nicholson.

Del CAÑIZO, JA., 1991. Palmeras. Bilbao: Grafo.

ESCALANTE-EROSA, F., GAMBOA-LEÓN, MR., LECHER, JG., ARROYO-SERRALTA, GA., ZIZUMBO-VILLAREAL, D., OROPEZA-SALIN, C. and PEÑA-RODRÍGUEZ, LM., 2002. Major Components from the Epicuticular Wax of Cocos nucifera. Revista de la Sociedad Química de México, vol. 46, no. 3 , p. 247-250.

GARCÍA, S., HEINZEN, H., HUBBUCH, C., MARTÍNEZ, R., DEVRIES, JX. and MOYNA, P., 1995. Triterpene methyl ethers from Palmae epicuticular waxes. Phytochemistry, vol. 39, no. 6, p. 1381-1382.

GLASSMAN, SF., 1972. Dahlgren's index of American palms. Stuttgart: Straus and Cramer. Phanerogamarum Monographie. Tomus VI. Revision of B.E.

HENDERSON, A., 1988. Pollination biology of economically important palms. In BALICK, MJ. (Ed.). The palm-tree of life: biology, utilization and conservation. Advances in Economic Botany, vol. 6. p. 36-41.
HENDERSON, A., GALEANO, G. and BERNAL, G., 1995. Field guide to the palms of the Americas. Princeton: Princeton Univ. Press.

IRIARTE, J., HOLST, I., MAROZZI, O., LISTOPAD, C., ALONSO, E., RINDERKNECHT, A. and MONTAÑA, J., 2005. Evidence for cultivar adoption and emerging complexity during the mid-Holocene in the La Plata basin. Nature, vol. 432, p. 614-617.

JONES, DL., 1994. Palms throughout the world. Washington: Smithsonian Press.

KOLATTUKUDY,PE.(Ed.)., 1976. Chemistry and biochemistry of natural waxes. Amsterdam: Elsevier.

LOMBARDO, A., 1964. Flora arbórea y arborescente del Uruguay. 2 ed. Montevideo: Concejo Dept. Montevideo.

LOTSCHERT, W., 1985. Palmen. Stuttgart: Ulmer.

MAFFEI, M. and SCANNERINI, S., 1993. Fatty acid variability from non-polar lipids in some Lamiaceae. Biochemical Systematic and Ecology, vol. 21, no. 4, p. 475-486.

MOORE, HE. and UHL, NW., 1982. Major trends of evolution in palms. The Botanical Review, vol. 48, no. 1, p. 1-69.

REITZ, R., 1974. Palmeiras. In REITZ, PR. (Ed.). Flora Ilustrada Catarinense. Itajaí: Herbário Barbosa Rodrigues.

TOMLINSON, PB., 1961. Palmae. In METCALFE, CR. (Ed.). Anatomy of the Monocotyledons II. Oxford: Clarendon.

VIEIRA, VF., GRAYER, RJ., PATON, A. and SIMON, JE., 2001. Genetic diversity of Ocimum gratissimum L. based on volatile oil constituents, flavonoids and RAPD markers. Biochemical Systematic and Ecology, vol. 29, no. 3, p. 287-304.

XU, R., FAZIO, GC. and MATSUDA, SPT., 2004. On the origins of triterpenoid skeletal diversity. Phytochemistry, vol. 65 , no. 3 , p. 261-291. 
